\title{
Frequency of irrigation with saline water in sugar-apple seedlings produced on substrate with polymer
}

\author{
Aldeir R. Silva ${ }^{1}$, Francisco T. C. Bezerra ${ }^{2}$, Lourival F. Cavalcante ${ }^{2}$, \\ Walter E. Pereira ${ }^{3}$, Leandro M. Araújo ${ }^{4}$ \& Marlene A. F. Bezerra ${ }^{2}$ \\ ${ }^{1}$ Universidade São Paulo/Escola Superior de Agricultura “Luiz de Queiroz"/Programa de Pós-Graduação em Fisiologia e Bioquímica de Plantas. Piracicaba, \\ SP. E-mail: aldeironaldo@usp.br (Corresponding author) - ORCID: 0000-0002-9829-8794 \\ ${ }^{2}$ Universidade Federal da Paraíba/Centro de Ciências Agrárias/Programa de Pós-Graduação em Agronomia. Areia, PB. E-mail: bezerra_ftc@yahoo.com.br - \\ ORCID: 0000-0002-9185-2641; lofeca@cca.ufpb.br - ORCID: 0000-0002-8827-4713; marlene_agro@hotmail.com - ORCID: 0000-0002-5108-836X \\ ${ }^{3}$ Universidade Federal da Paraíba/Centro de Ciências Agrárias. Areia, PB. E-mail: wep@cca.ufpb.br - ORCID: 0000-0003-1085-0191 \\ ${ }^{4}$ Universidade Estadual Paulista "Júlio de Mesquita Filho"/Faculdade de Ciências Agronômicas/Departamento de Engenharia Rural. Botucatu, SP. E-mail: \\ leandro_moscoso@hotmail.com - ORCID:0000-0001-6621-7155
}

\section{Key words:}

Annona squamosa

soil amendment

container volume

seedling quality

\begin{abstract}
A B S T R A C T
The objective of this work was to evaluate the growth of sugar-apple seedlings under irrigation management with saline water in a substrate with soil amendment. Treatments were obtained from the arrangement between polymer doses $\left(0,0.2,0.6,1.0\right.$ and $\left.1.2 \mathrm{~g} \mathrm{dm}^{-3}\right)$ and levels of irrigation water electrical conductivity $\left(0.3,1.1,2.7,4.3\right.$ and $\left.5.0 \mathrm{dS} \mathrm{m}^{-1}\right)$, associated with irrigation frequencies (daily and every alternate day), and two additional treatments to evaluate container volume $\left(1.30\right.$ and $\left.0.75 \mathrm{dm}^{3}\right)$, using a randomized complete block design, with four replicates. At 120 days after sowing, the variables substrate salinity, stem diameter, plant height, number of leaves and Dickson quality index were determined. Data were submitted to analyses of variance, regression and contrast. Substrate salinity increased with the increase in irrigation water electrical conductivity and polymer doses. Growth and quality of the seedlings were reduced with increasing irrigation water salinity, and highest values of the variables were obtained in seedlings under daily irrigation. Container with larger volume led to higher growth. The use of hydrated polymer at the adopted levels had no effect on growth and quality of seedlings, requiring further studies. To produce sugarapple seedlings with better quality, irrigation frequency should be daily and water electrical conductivity should be lower than $2 \mathrm{dS} \mathrm{m}^{-1}$.
\end{abstract}

Palavras-chave:

Annona squamosa condicionador do solo volume de recipiente qualidade de mudas

\section{Frequência de irrigação com água salina em mudas de pinha produzidas em substrato com polímero}

\begin{abstract}
R E S U M O
Objetivou-se com o trabalho avaliar a formação de mudas de pinha sob o manejo da irrigação com água salina em substrato com condicionante de solo. Os tratamentos foram obtidos do arranjo entre doses de polímero $\left(0 ; 0,2 ; 0,6 ; 1,0\right.$ e $\left.1,2 \mathrm{~g} \mathrm{dm}^{-3}\right)$ e condutividade elétrica da água de irrigação $\left(0,3 ; 1,1 ; 2,7 ; 4,3\right.$ e 5,0 dS m$\left.~^{-1}\right)$, associado a frequências de irrigação (diária e alternada), e mais dois tratamentos adicionais para avaliar o volume de recipiente $(1,30 \mathrm{e}$ $0,75 \mathrm{dm}^{3}$ ), utilizando o delineamento de blocos casualizados, com quatro repetições. Aos 120 dias após a semeadura, determinou-se as variáveis salinidade do substrato, diâmetro do caule, altura, número de folhas e índice de qualidade de Dickson. Os dados foram submetidos às análises de variância, regressão e contraste. A salinidade do substrato aumentou com a elevação da condutividade elétrica da água de irrigação e com as doses de polímero. $\mathrm{O}$ crescimento e a qualidade das mudas foram reduzidos com o aumento da salinidade da água de irrigação, sendo os maiores valores das variáveis obtidos sob irrigação diária. Recipiente de maior volume proporcionou maior crescimento. $\mathrm{O}$ uso de polímero hidratado nos níveis adotados não apresentou respostas ao crescimento e qualidade das mudas, necessitando mais estudos. Para produção de mudas de pinha de melhor qualidade deve ser realizada irrigação diária, utilizando água de condutividade elétrica menor que $2 \mathrm{dS} \mathrm{m}^{-1}$.
\end{abstract}




\section{INTRODUCTION}

Annona squamosa L., popularly known as sugar-apple, is a short tree belonging to the Annonaceae family. Its yield in Brazil is still low, below $6 \mathrm{t} \mathrm{ha}^{-1}$, and the Northeast is the main producing region (Lemos, 2014). In general, the crop is produced in small areas using low technological level (Oliveira et al., 2016). In the planting of the orchards, several phytotechnical aspects must be considered and one of the first and fundamental ones is the acquisition or production of seedlings, because their vigor may affect crop yield (Santos et al., 2017).

One of the main problems for production in Northeast Brazil is the availability of water, as well as its quantity and/ or quality. Presence of high quantity of salts, which would correspond to electrical conductivity values above $4 \mathrm{dS} \mathrm{m}^{-1}$, affects water absorption and cause toxic effects (Munns \& Tester, 2008; Taiz et al., 2017), directly hampering physiological and biochemical processes (Prisco et al., 2016), resulting in lower growth of seedlings (Cavalcante et al., 2010; Sousa et al., 2011; Nunes et al., 2012; Sá et al., 2013, 2015; Oliveira et al., 2017).

The use of water-absorbing polymer has become a low-cost measure aimed at more efficient use of water and reduction of problems related to salinity (Kant \& Turan, 2011; Ljubojevi et al., 2017), as it is possible to reduce irrigation depth and consequently the addition of salts. Furthermore, management in irrigation frequency can be determinant in water availability (Navroski et al., 2015), as well as the adjustment of container volume, which is directly linked to the availability of space and nutrients for root growth, possibly leading to greater growth and vigor of seedlings (Costa et al., 2009a,b; Vallone et al., 2010; Mesquita et al., 2012; Santos et al., 2012). However, larger containers are more expensive and, therefore, it is essential to reduce container volume to minimize costs, but without compromising seedling quality.

Thus, this work was conducted to evaluate substrate salinity and growth of sugar-apple seedlings as affected by irrigation frequency, irrigation water electrical conductivity, waterabsorbing polymer and container volume.

\section{Material AND Methods}

The study was conducted in the screened greenhouse (6 $6^{\circ} 58^{\prime} 9.4^{\prime \prime} \mathrm{S}, 35^{\circ} 42^{\prime} 59.3^{\prime \prime} \mathrm{W}$ and $522 \mathrm{~m}$ of altitude) of the Department of Soils and Rural Engineering of the Center of Agrarian Sciences, at the Federal University of Paraíba, situated in the municipality of Areia, Paraíba State, Brazil.

Treatments were arranged in a $\left[\left(2^{2}+2 \times 2+1\right) \times 2\right]+2$ scheme, where $\left(2^{2}+2 \times 2+1\right)$ was obtained by combinations between five doses of the polymer Hydroplan-EB/HyA ( 0 ; $0.2 ; 0.6 ; 1.0$ and $\left.1.2 \mathrm{~g} \mathrm{dm}^{-3}\right)$ and five levels of irrigation water electrical conductivity $\left(0.3 ; 1.1 ; 2.7 ; 4.3\right.$ and $\left.5.0 \mathrm{dS} \mathrm{m}^{-1}\right)$ using the Box's Central Composite Design, associated with two irrigation frequencies (daily and alternating), and two additional treatments to evaluate the effect of container volume $(0.75$ and $1.30 \mathrm{dm}^{3}$ ), as can be observed in Table 1 . The statistical
Table 1. Scheme between the levels of the factors ( HyA Polymer; ECiw - Electrical conductivity of irrigation water; IF - Irrigation frequency; CtV - Container volume) used in the experiment

\begin{tabular}{|c|c|c|c|c|c|c|}
\hline \multirow[b]{2}{*}{ Treat. $^{1}$} & \multicolumn{2}{|c|}{ Levels $^{2}$} & \multicolumn{2}{|c|}{ Doses/Concentrations } & \multirow[b]{2}{*}{ IF } & \multirow[b]{2}{*}{$\begin{array}{c}\text { CtV } \\
\left(\mathrm{dm}^{3}\right)\end{array}$} \\
\hline & HyA & ECiw & $\begin{array}{c}\text { HyA } \\
\left(\mathrm{g} \mathrm{dm}^{-3}\right)\end{array}$ & $\begin{array}{c}\text { ECiw } \\
\left(\mathrm{dS} \mathrm{m} \mathrm{m}^{-1}\right)\end{array}$ & & \\
\hline 1 & -1 & -1 & 0.2 & 1.1 & Daily & 1.30 \\
\hline 2 & -1 & 1 & 0.2 & 4.3 & Daily & 1.30 \\
\hline 3 & 1 & -1 & 1.0 & 1.1 & Daily & 1.30 \\
\hline 4 & 1 & 1 & 1.0 & 4.3 & Daily & 1.30 \\
\hline 5 & $-1.41(-\alpha)^{3}$ & 0 & 0.0 & 2.7 & Daily & 1.30 \\
\hline 6 & $1.41(\alpha)$ & 0 & 1.2 & 2.7 & Daily & 1.30 \\
\hline 7 & 0 & $-1.41(-\alpha)$ & 0.6 & 0.3 & Daily & 1.30 \\
\hline 8 & 0 & $1.41(\alpha)$ & 0.6 & 5.0 & Daily & 1.30 \\
\hline 9 & 0 & 0 & 0.6 & 2.7 & Daily & 1.30 \\
\hline 10 & -1 & -1 & 0.2 & 1.1 & Alternate day & 1.30 \\
\hline 11 & -1 & 1 & 0.2 & 4.3 & Alternate day & 1.30 \\
\hline 12 & 1 & -1 & 1.0 & 1.1 & Alternate day & 1.30 \\
\hline 13 & 1 & 1 & 1.0 & 4.3 & Alternate day & 1.30 \\
\hline 14 & $-1.41(-\alpha)$ & 0 & 0.0 & 2.7 & Alternate day & 1.30 \\
\hline 15 & $1.41(\alpha)$ & 0 & 1.2 & 2.7 & Alternate day & 1.30 \\
\hline 16 & 0 & $-1.41(-\alpha)$ & 0.6 & 0.3 & Alternate day & 1.30 \\
\hline 17 & 0 & $1.41(\alpha)$ & 0.6 & 5.0 & Alternate day & 1.30 \\
\hline 18 & 0 & 0 & 0.6 & 2.7 & Alternate day & 1.30 \\
\hline 19 & 0 & 0 & 0.6 & 2.7 & Daily & 0.75 \\
\hline 20 & 0 & 0 & 0.6 & 2.7 & Alternate day & 0.75 \\
\hline
\end{tabular}

${ }^{1}$ Number of treatments for each arrangement between polymer doses and levels of irrigation water electrical conductivity $=2^{k}+2 k+1\left(k=2, n^{0}\right.$ of factors) $\therefore 2^{2}+2 \times 2+1=9$; ${ }^{2}$ Levels established according to the Box's central matrix; ${ }^{3} \alpha=\sqrt{ } k$

design was randomized complete blocks, with four replicates, and the experimental unit consisted of four containers with one plant each.

The substrate consisted of a mixture of soil, sand and bovine manure at 3:1:1 proportion, respectively. The soil was collected in the $0-20 \mathrm{~cm}$ layer of a profile of Red Yellow Latosol (Santos et al., 2013), at the Chã do Jardim experimental station, located in the municipality of Areia, Paraíba State, Brazil. Fertility attributes were: 5.9 of $\mathrm{pH}, 0.46 \mathrm{dS} \mathrm{m}{ }^{-1}$ of electrical conductivity ( 1 soil -2.5 water suspension); $0.50 ; 9.47 ; 1.74$; $1.28 ; 0.23$ and $0.88 \mathrm{cmol}_{\mathrm{c}} \mathrm{dm}^{-3}$ of $\mathrm{Al}^{3+}, \mathrm{H}^{+}+\mathrm{Al}^{3+}, \mathrm{Ca}^{2+}, \mathrm{Mg}^{2+}, \mathrm{Na}^{+}$, $\mathrm{K}^{+}$, respectively, $45 \mathrm{mg} \mathrm{dm}^{-3}$ of phosphorus and $24.3 \mathrm{~g} \mathrm{dm}^{-3}$ of organic matter. The saturation extract, which indicates soil salinity, had $\mathrm{pH}$ of 5.9 and electrical conductivity of $1.97 \mathrm{dS} \mathrm{m}^{-1}$. Physical characteristics were: $68.67 \%$ of sand, $18.17 \%$ of silt and $13.16 \%$ of clay, 1.35 and $2.64 \mathrm{~g} \mathrm{~cm}^{-3}$ of bulk and particle densities, respectively, and porosity of $48.86 \%$. Analyses of substrate were carried out according the methodologies compiled by Teixeira et al. (2017).

In substrate preparation, phosphorus contents were increased to 300 and $100 \mathrm{mg} \mathrm{kg}^{-1}$ of nitrogen were applied (Novais et al., 1991), using single superphosphate and urea, respectively. The water-absorbing polymer was hydrated in distilled water before being mixed with the substrate. Irrigation was performed with saline waters, prepared by the addition of sodium $\left(\mathrm{Na}^{+}\right)$, calcium $\left(\mathrm{Ca}^{2+}\right)$ and magnesium $\left(\mathrm{Mg}^{2+}\right)$ ions in the form of chloride, following the proportion of $5: 2: 1$, respectively, on mass basis (Silva Júnior et al., 1999), in the public-supply water, with electrical conductivity of $0.3 \mathrm{dS} \mathrm{m} \mathrm{m}^{-1}$. In the irrigation with alternating frequency, every two days, a volume equivalent to $70 \%$ of that applied in the daily frequency was applied. The daily water depth was applied to maintain the substrate close to field capacity, until drainage began. 
At 120 days after sowing, the seedlings were evaluated for the following parameters: stem diameter at substrate level (SD), using a digital caliper; plant height $(\mathrm{PH})$, measured with millimetric ruler from collar to apical bud; number of leaves $(\mathrm{NL})$, determined by counting. After removal of sugar-apple seedlings, the substrate was sieved and electrical conductivity was measured in the substrate-distilled water suspension at 1:2.5 proportion, respectively. Dickson quality index (DQI) was calculated by the formula (Dickson et al., 1960):

$$
\mathrm{DQI}=\frac{\mathrm{TDM}}{\frac{\mathrm{PH}}{\mathrm{SD}}+\frac{\mathrm{DMS}}{\mathrm{RDM}}}
$$

where:

TDM - total dry matter, g;

$\mathrm{PH}$ - plant height, $\mathrm{cm}$;

$\mathrm{SD}$ - stem diameter, $\mathrm{mm}$;

DMS - dry matter of shoots, stem + leaves, g; and,

RDM - root dry matter, g.

The data were subjected to analysis of variance. Quantitative effects of polymer doses and levels of irrigation water electrical conductivity were subjected to regression analysis, whereas irrigation frequency and container volume were evaluated by contrasts, based on F test $(\mathrm{p} \leq 0.05)$. Statistical analysis was carried out using the software $\mathrm{SAS}^{\circ}$ University Edition.

\section{RESUlTS AND Discussion}

The effects of irrigation water electrical conductivity, water-absorbing polymer, irrigation frequency and container volume on the electrical conductivity of the substrate, growth and quality of sugar-apple seedlings are presented in Table 2.

Substrate electrical conductivity was affected by irrigation water salinity and polymer doses (Table 2). Irrigation increased substrate salinity, which changed from 0.5 to $2.3 \mathrm{dS} \mathrm{m}^{-1}$ ( $360 \%$ increase) from the initial condition to the condition of irrigation with $0.3 \mathrm{dS} \mathrm{m}^{-1}$ water, being intensified with the increment in irrigation water electrical conductivity (Figure 1A). It was estimated that unit increase in irrigation water electrical conductivity led to increment of $0.22 \mathrm{dS} \mathrm{m}^{-1}$ or $9 \%$ in substrate salinity, which changed from 2.3 to $3.3 \mathrm{dS} \mathrm{m}^{-1}$, respectively, at salinity levels of 0.3 and $5.0 \mathrm{dS} \mathrm{m}^{-1}$. Bezerra et al. (2014) observed that the non-saline character of the substrate used in the production of passion fruit seedlings changed to saline when irrigated using water from 0.57 to $1.1 \mathrm{dS} \mathrm{m}^{-1}$ and to salic with water above $1.1 \mathrm{dS} \mathrm{m}^{-1}$, demonstrating that even water with no limitations with respect to salinity can alter the saline character of the substrate.

Increasing polymer doses had effect on substrate electrical conductivity (Figure 1B), which showed maximum value of $2.8 \mathrm{dS} \mathrm{m}^{-1}$ at the dose of $0.6 \mathrm{~g}$ of hydrogel $\mathrm{kg}^{-1}$ of substrate, whereas doses higher than $0.6 \mathrm{~g} \mathrm{~kg}^{-1}$ caused reduction in

Table 2. Summary of analyses of variance, regression and contrasts for substrate electrical conductivity (EC), stem diameter at soil level (SD), plant height (PH), number of leaves (NL), and Dickson quality index (DQI) of sugar-apple seedlings at 120 days after sowing as affected by irrigation water electrical conductivity (ECiw), water-absorbing polymer $(\mathrm{P})$, irrigation frequency $(\mathrm{F})$ and container volume

\begin{tabular}{|c|c|c|c|c|c|c|}
\hline \multirow{2}{*}{ Source of variation } & \multirow{2}{*}{ DF } & \multicolumn{5}{|c|}{ Mean square } \\
\hline & & EC & SD & $\mathrm{PH}$ & $\mathrm{NL}$ & DQI \\
\hline Block & 3 & $0.9423^{\star \star}$ & $1.0090 * \star$ & $12.1181^{\mathrm{ns}}$ & $3.6468^{\text {ns }}$ & $0.0181 *$ \\
\hline Treatment & (19) & $0.7834^{\star *}$ & $1.4811^{* *}$ & $98.4471^{\star \star}$ & $18.2326^{\star \star}$ & $0.0288^{* *}$ \\
\hline Frequency (F) & 1 & $0.1741^{\mathrm{ns}}$ & $6.3452^{\star \star}$ & 397.2676 ** & $92.0649 * *$ & $0.0234^{*}$ \\
\hline Factorial ${ }^{1} \times \mathrm{F}$ & 8 & $0.3314^{\mathrm{ns}}$ & $0.0758^{\text {ns }}$ & $21.7434^{\star}$ & $2.0378^{\text {ns }}$ & $0.0055^{\text {ns }}$ \\
\hline Residual & 57 & 0.2072 & 0.1328 & 9.0327 & 1.8358 & 0.0055 \\
\hline CV (\%) & & 16.47 & 8.15 & 13.97 & 12.53 & 31.25 \\
\hline \multirow[t]{2}{*}{ Mean } & & $2.8 \mathrm{dS} \mathrm{m}^{-1}$ & $4.47 \mathrm{~mm}$ & $21.5 \mathrm{~cm}$ & 11 units & 0.24 \\
\hline & & \multicolumn{5}{|c|}{ Regression $^{2}$} \\
\hline P-Linear & 1 & $0.0230^{\text {ns }}$ & - & - & - & - \\
\hline P-Quadratic & 1 & $0.8460 *$ & - & - & - & - \\
\hline ECiw-Linear & 1 & $0.1772^{\star \star}$ & - & - & - & - \\
\hline ECiw-Quadratic & 1 & $0.0330^{\text {ns }}$ & - & - & - & - \\
\hline P-Linear x ECiw-Linear & 1 & $0.0072^{\text {ns }}$ & - & - & - & - \\
\hline & & \multicolumn{5}{|c|}{ Regression³/Daily Irrigation } \\
\hline P-Linear & 1 & - & $0.0278^{\text {ns }}$ & $5.5641^{\text {ns }}$ & $0.0225^{\text {ns }}$ & $0.0000^{\text {ns }}$ \\
\hline P-Quadratic & 1 & - & $0.0343^{\text {ns }}$ & $7.4526^{\text {ns }}$ & $4.5625^{\mathrm{ns}}$ & $0.0059^{\text {ns }}$ \\
\hline ECiw-Linear & 1 & - & $10.7664^{* *}$ & $889.1070^{* *}$ & $103.1627^{\star \star}$ & $0.2983^{\star *}$ \\
\hline ECiw-Quadratic & 1 & - & $0.2333^{\text {ns }}$ & $15.2106^{\mathrm{ns}}$ & $6.3144^{\text {ns }}$ & $0.0015^{\text {ns }}$ \\
\hline \multirow[t]{2}{*}{ P-Linear x ECiw-Linear } & 1 & - & $0.0713^{\text {ns }}$ & $2.0754^{\text {ns }}$ & $0.0986^{\text {ns }}$ & $0.0005^{\text {ns }}$ \\
\hline & & \multicolumn{5}{|c|}{ Regression ${ }^{3} /$ Alternating Irrigation } \\
\hline P-Linear & 1 & - & $0.0091^{\mathrm{ns}}$ & $0.2474^{\text {ns }}$ & $0.0025^{\text {ns }}$ & $0.0015^{\mathrm{ns}}$ \\
\hline P-Quadratic & 1 & - & $0.0007^{\mathrm{ns}}$ & $19.7635^{\text {ns }}$ & $4.7977^{\mathrm{ns}}$ & $0.0000^{\text {ns }}$ \\
\hline ECiw-Linear & 1 & - & $5.9833^{* *}$ & $181.8127^{\star \star}$ & $34.1364 * \star$ & $0.1005^{\star *}$ \\
\hline ECiw-Quadratic & 1 & - & $0.0652^{\text {ns }}$ & $41.7601^{\star}$ & $5.7092^{\text {ns }}$ & $0.0017^{\text {ns }}$ \\
\hline \multirow[t]{2}{*}{ P-Linear $x$ ECiw-Linear } & 1 & - & $0.0652^{\text {ns }}$ & $0.0064^{\mathrm{ns}}$ & $0.9597^{\text {ns }}$ & $0.0065^{\text {ns }}$ \\
\hline & & \multicolumn{5}{|c|}{ Contrasts $^{4}$} \\
\hline Y1 & 1 & $0.8065^{\mathrm{ns}}$ & $0.8337^{\star}$ & $29.0703^{\text {ns }}$ & $14.0009^{* *}$ & $0.0381 *$ \\
\hline Y2 & 1 & $0.0025^{\mathrm{ns}}$ & $1.2807^{* *}$ & $74.5217^{\star *}$ & $29.3889 * *$ & $0.0087^{\text {ns }}$ \\
\hline
\end{tabular}

${ }^{1}$ Refers to the combinations between levels of irrigation water electrical conductivity and water-absorbing polymer doses, using the Box's central composite; ${ }^{2} \mathrm{Absence}$ of effect of irrigation frequency; ${ }^{3}$ Considering the effect of irrigation frequency; ${ }^{4}$ Effect of container volume $\left(1.30 \times 0.75 \mathrm{dm}^{3}\right)$ at daily and (Y1) and alternating (Y2) irrigation frequencies; ${ }^{*}$, * and ${ }^{\star \star}$ Not significant and significant at 0.05 and 0.01 probability levels by $\mathrm{F}$ test, respectively 

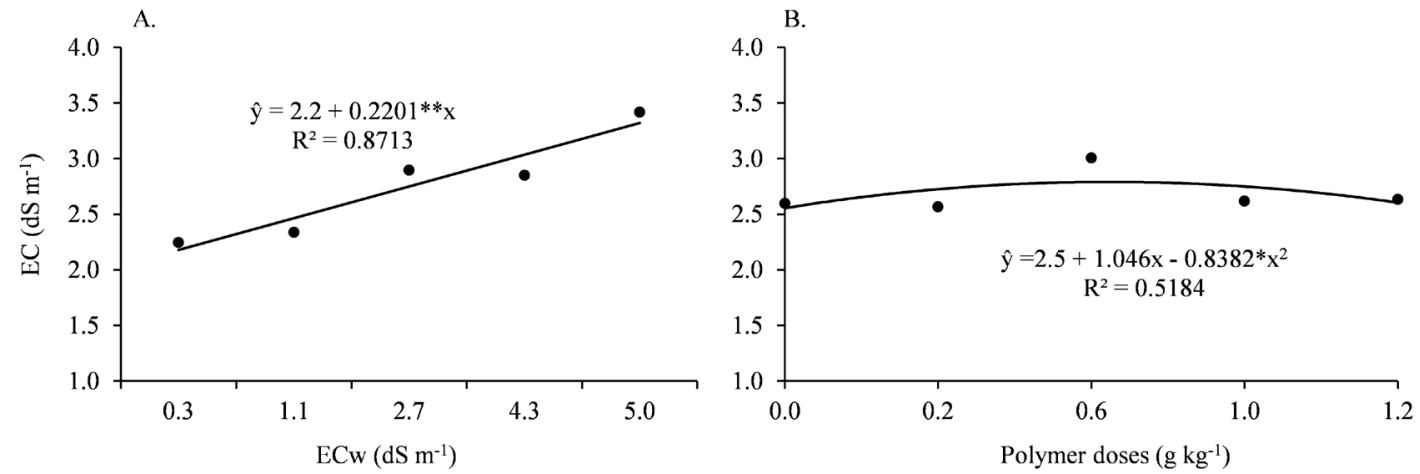

* and **: Significant at 0.05 and 0.01 probability levels by $\mathrm{F}$ test, respectively

Figure 1. Substrate electrical conductivity after production of sugar-apple seedlings, as a function of irrigation water electrical conductivity (A) and water-absorbing polymer (B)
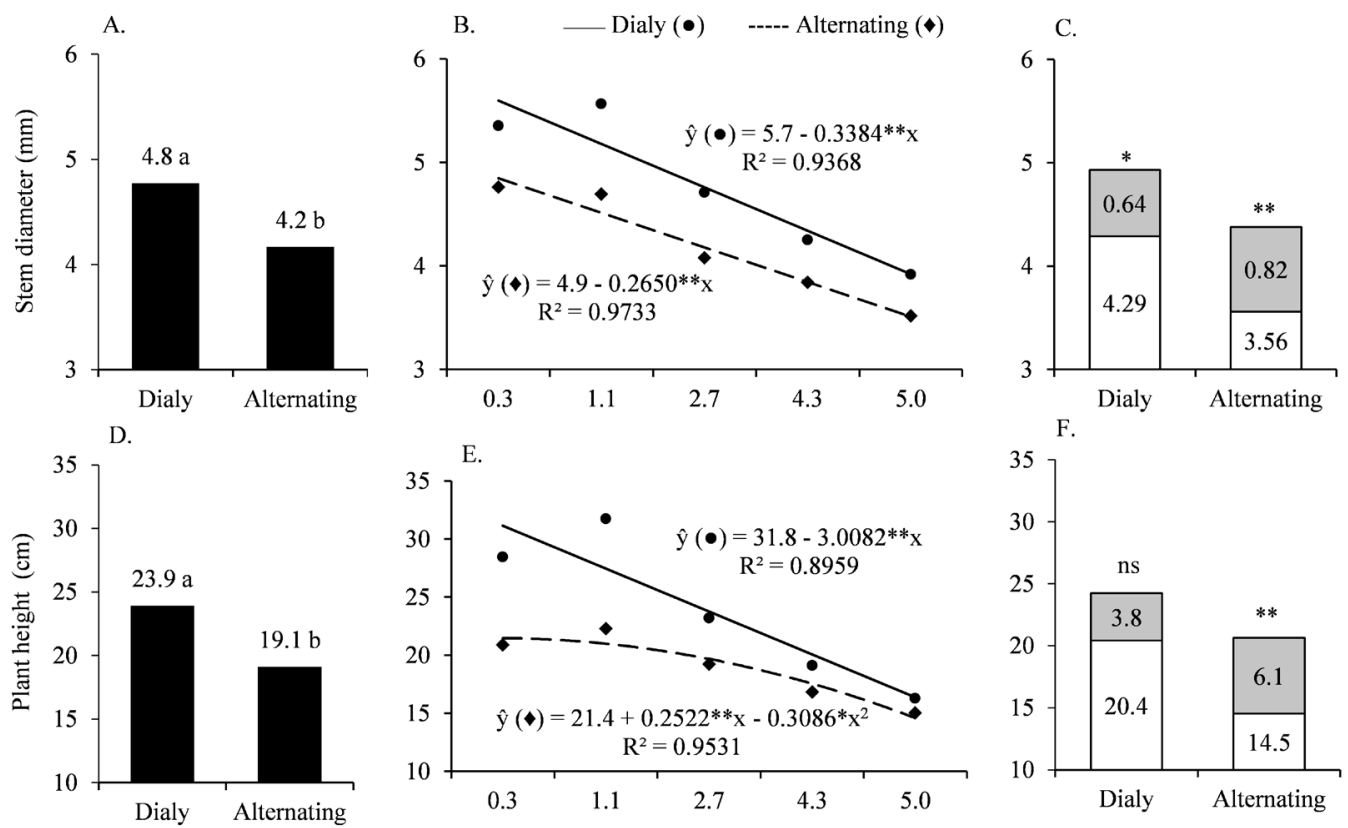

G.
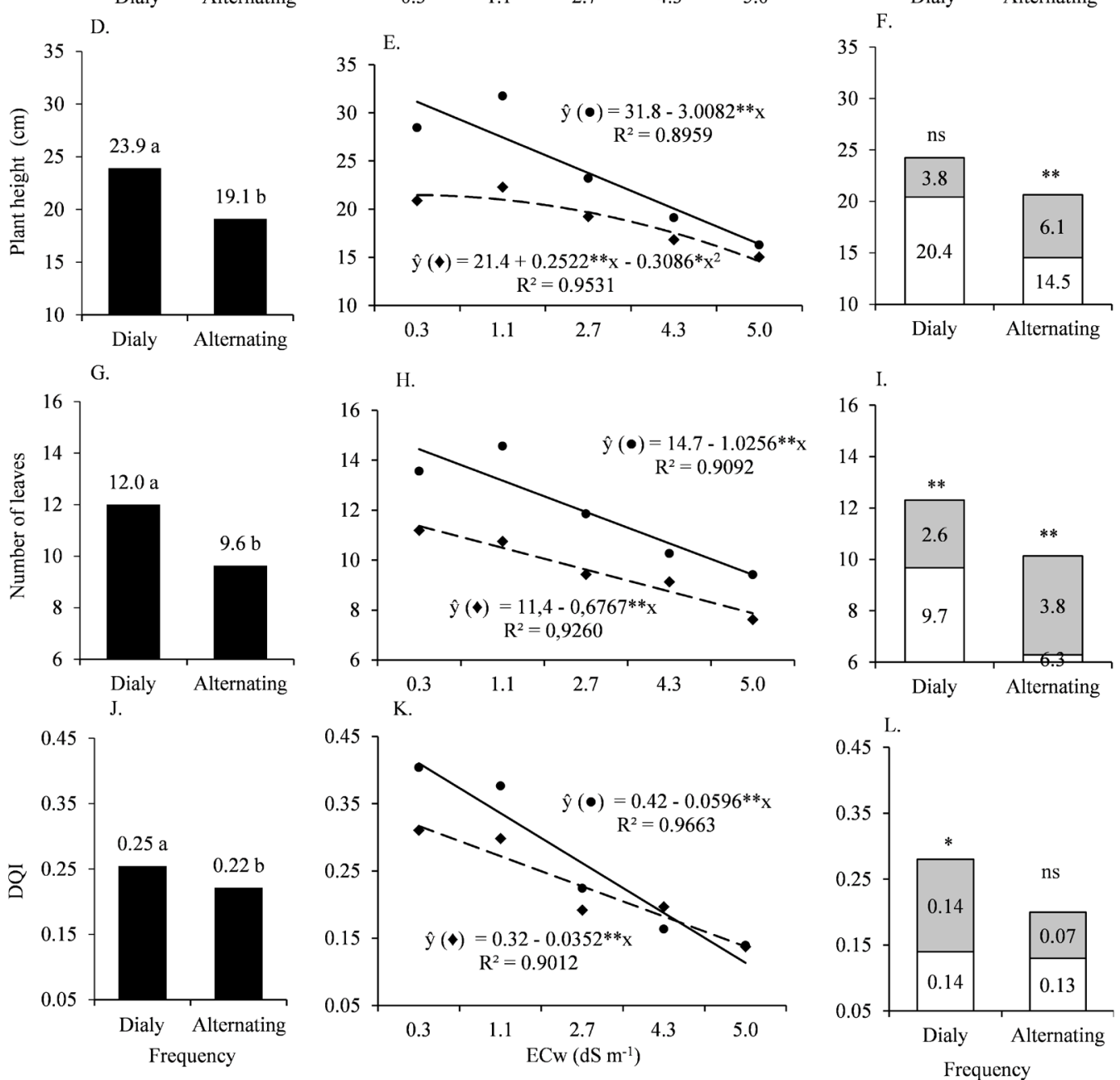

Means followed by the same letter do not differ by $F$ test $(p \leq 0.05)$. ns , ${ }^{*}$ and ${ }^{* *}$ : Not significant and significant at 0.05 and 0.01 probability by $F$ test, respectively. $\square$ Actual effect of the contrast: large container $\left(1.30 \mathrm{dm}^{3}\right)$ - small container $\left(0.75 \mathrm{dm}^{3}\right)$

Figure 2. Stem diameter at soil level $(A, B, C)$, plant height $(D, E, F)$, number of leaves $(G, H, I)$ and Dickson quality index $(\mathrm{J}, \mathrm{K}, \mathrm{L})$ in sugar-apple seedlings as a function of irrigation frequency, irrigation water electrical conductivity and container volume at daily and alternating irrigation frequency, respectively 
substrate electrical conductivity. Navroski et al. (2015), mixing commercial substrate with hydrogel, also found increased salinity with the increment in polymer doses.

Growth and quality of sugar-apple seedlings were affected by irrigation frequency, water salinity and container volume (Table 2). Daily frequency of irrigation led to the highest values of stem diameter $(4.8 \mathrm{~mm})$, plant height $(23.9 \mathrm{~cm})$, number of leaves (12 units) and Dickson quality index (0.25), and reductions of $13,20,20$ and $12 \%$ were caused when the alternating frequency was adopted (Figures 2A, D, G and J, respectively). This trend was also observed by Zonta et al. (2009), in coffee seedlings, when the increase in irrigation interval reduced the growth in diameter and height. Carvalho et al. (2013), in yellow passion fruit seedlings, and Tsukamoto Filho et al. (2013), in seedlings of Myracrodruon urundeuva Fr. All of them observed that the growth in stem diameter, height and number of leaves decreased when irrigation frequency changed from daily to alternating, and these results can be associated with the water stress that may occur as the intervals between irrigations increase.

Increase in water salinity, at both irrigation frequencies, reduced growth and quality of sugar-apple seedlings. The reduction rates per unit increase in irrigation water electrical conductivity, at daily and alternating frequencies of irrigation, were, respectively, 5.9 and $5.4 \%(0.34$ and $0.26 \mathrm{~mm})$ for stem diameter (Figure 2B), 9.5 and on average 6\% (3.0 and on average $1.4 \mathrm{~cm}$ ) for plant height (Figure 2E), 7 and 6\% (1.0 and 0.7 leaf) for number of leaves (Figure $2 \mathrm{H}$ ) and 14.2 and $11 \%(0.06$ and 0.04$)$ for Dickson quality index (Figure $2 \mathrm{~K}$ ). Among these parameters, Dickson quality index is the most expressive to indicate the deleterious effect of salt stress of the irrigation water.

Lower growth and reduction in the quality of sugar-apple seedlings due to water salinity are related to the accumulation of salts in the substrate, which leads to a decrease in osmotic potential and consequently in water absorption (Taiz et al., 2017). According to Prisco et al. (2016), salinity directly hampers physiological and biochemical processes of plants. Reduction in the growth of seedlings under saline water irrigation has been reported in various crops, such as papaya (Cavalcante et al., 2010; Sá et al., 2013), cashew (Sousa et al., 2011), sugar-apple (Nunes et al., 2012; Sá et al., 2015) and jackfruit (Oliveira et al., 2017).

In regard to container volume, the effects were associated with the irrigation interval and, when significant, containers with larger volume led to higher means. Growth in diameter (Figure 2C) and number of leaves (Figure 2I) in sugar-apple seedlings, under daily irrigation, increased on average by $0.64 \mathrm{~mm}(15 \%)$ and 2.6 leaves (27\%). Under alternating frequency, the increments were $0.82 \mathrm{~mm}(23 \%)$ and 3.8 leaves (60\%), when the container volume changed from 0.75 to $1.30 \mathrm{dm}^{3}$.

For plant height, the gain with the increase in container volume was observed only under alternating frequency of irrigation, from 14.5 to $20.6 \mathrm{~cm}$ in the containers of 0.75 to $1.30 \mathrm{dm}^{3}$, respectively (Figure $2 \mathrm{~F}$ ). Lemos et al. (2010), evaluating container volumes in the production of sugar-apple rootstocks, also found higher values of stem diameter, height and number of leaves when the seedlings were produced in containers with larger volume.
Dickson quality index was also affected by container volume, but only under daily frequency of irrigation, increasing by $100 \%$ when the seedlings were produced in the larger container (Figure 2L). Negative effect of the reduction in container volume has also been observed in seedlings of coffee (Vallone et al., 2010), papaya (Mesquita et al., 2012) and passion fruit (Costa et al., 2009a, b). These results can be caused by a greater development and vigor of the root system of plants grown in larger containers, which led to greater availability of nutrients and porous space for root growth (Costa et al., 2009b).

\section{Conclusions}

1. The use of hydrated polymer at the adopted levels had no effect on growth and quality of the seedlings, requiring further studies.

2. For the production of sugar-apple seedlings, irrigation frequency should be daily and water electrical conductivity should be lower than $2 \mathrm{dS} \mathrm{m}^{-1}$.

3. Sugar-apple seedlings with greater growth and quality are produced in larger containers $\left(1.30 \times 0.75 \mathrm{dm}^{3}\right)$.

\section{Acknowledgments}

To the company Hydroplan for providing the waterabsorbing polymer.

\section{Literature Cited}

Bezerra, M. A. F.; Pereira, W. E.; Bezerra, F. T. C.; Cavalcante, L. F.; Medeiros, S. A. S. Água salina e nitrogênio na biomassa de mudas de maracujazeiro amarelo. Revista Agropecuária Técnica, v.35, p.150-160, 2014.

Carvalho, R. P.; Cruz, M. C. M.; Martins, L. M. Frequência de irrigação utilizando polímero hidroabsorvente na produção de mudas de maracujazeiro-amarelo. Revista Brasileira de Fruticultura, v.35, p.518-526, 2013. https://doi.org/10.1590/ S0100-29452013000200022

Cavalcante, L. F.; Cordeiro, J. C.; Nascimento, J. A. M.; Cavalcante, I. H. L.; Dias, T. J. Fontes e níveis da salinidade da água na formação de mudas de mamoeiro cv. sunrise solo. Semina: Ciências Agrárias, v.31, p.1281-1290, 2010. https://doi.org/10.5433/16790359.2010v31n4Sup1p1281

Costa, E.; Rodrigues, E. T.; Alves, V. B.; Santos, L. D.; Vieira, L. C. R. Efeitos da ambiência, recipientes e substratos no desenvolvimento de mudas de maracujazeiro-amarelo em Aquidauana-MS. Revista Brasileira de Fruticultura, v.31, p.236-244. 2009a. https://doi. org/10.1590/S0100-29452009000100033

Costa, E.; Santos, L. C. R.; Vieira, L. C. R. Produção de mudas de mamoeiro utilizando diferentes substratos, ambientes de cultivo e recipientes. Engenharia Agrícola, v.29, p.528-537, 2009b. https:// doi.org/10.1590/S0100-69162009000400003

Dickson, A.; Leaf, A. L.; Hosner, J. F. Quality appraisal of white spruce and white pine seedling stock in nurseries. Florest Chronicle, v.36, p.10-13, 1960. https://doi.org/10.5558/tfc36010-1

Kant, A. C.; Turan, M. Hydrogel substrate alleviates salt stress with increase antioxidant enzymes activity of bean (Phaseolus vulgaris L.) under salinity stress. Journal of Agricultural Research, v.6, p.715-724, 2011. 
Lemos, E. E. P. de. A produção de anonáceas no Brasil. Revista Brasileira de Fruticultura, v.36 (edição especial), p.77-85, 2014.

Lemos, E. E. P. de; Salvador, T. de L.; Santos, M. Q. C. dos; Rezende, L. de P.; Salvador, T. de L.; Lima, H. M. A. Produção de porta-enxertos em tubetes e enxertia precoce da pinheira (Annona squamosa L.). Revista Brasileira de Fruticultura, v.32, p.865-873, 2010. https:// doi.org/10.1590/S0100-29452010005000095

Ljubojevi, M.; Ognjanov, V.; Maksimovic, I.; Cukanovic, J.; Dulic, J.; Szabo, Z.; Szabo, E. Effects of hydrogel on growth and visual damage of ornamental salvia species exposed to salinity. CLEAN - Soil, Air, Water, v.45, p.1-8, 2017. https://doi.org/10.1002/clen.201600128

Mesquita, E. F.; Chaves, L. H. G.; Freitas, B. V.; Silva, G. A.; Sousa, M. V. R.; Andrade, R. Produção de mudas de mamoeiro em função de substratos contendo esterco bovino e volumes de recipientes. Revista Brasileira de Ciências Agrárias, v.7, p.58-65, 2012. https:// doi.org/10.5039/agraria.v7ila1448

Munns, R.; Tester, M. Mechanisms of salinity tolerance. Annual Review of Plant Biology, v.59, p.51-81, 2008. https://doi.org/10.1146/ annurev.arplant.59.032607.092911

Navroski, M. C.; Araujo, M. M.; Fior, C. S.; Cunha, F. da S.; Berghetti, A. L. P.; Pereira, M. de O. Uso de hidrogel possibilita redução da irrigação e melhora o crescimento inicial de mudas de Eucalyptus dunnii Maiden. Scientia Forestalis, v.43, p.467-476, 2015.

Novais, R. F. de; Neves, J. C. L.; Barros, N. F. de. Ensaio em ambiente controlado. In: Oliveira, A. J. de; Garrido, W. E.; Araújo, J. D. de; Lourenço, S. Métodos de pesquisa em fertilidade do solo. Brasília: Embrapa Informação Tecnológica, 1991. Cap.5, p.189-253.

Nunes, R. L. C.; Dias, N. da S.; Lima, M. V. da S.; Almeida, J. P. N. de; Costa, J. M. da. Produção de mudas de pinha (Annona squamosa L.) utilizando água de rejeito salino. Revista Verde de Agroecologia e Desenvolvimento Sustentável, v.7, p.1-6, 2012.

Oliveira, A. da S.; Castellani, M. A.; Nascimento, A. S. do; Moreira, A. A. Perfil do sistema de produção de pinha nos polos de fruticultura da Bahia, com ênfase nos aspectos fitossanitários da cultura. Extensão Rural, v.23, p.95-111, 2016. https://doi.org/10.5902/2318179613034

Oliveira, F. I. F. de; Souto, A. G. de L.; Cavalcante, L. F.; Medeiros, W. J. F. de; Bezerra, F. T. C.; Bezerra, M. A. F. Quality of jackfruit seedlings under saline water stress and nitrogen fertilisation. Semina: Ciências Agrárias, v.38, p.2337-2350, 2017. https://doi. org/10.5433/1679-0359.2017v38n4SUPLp2337

Prisco, J. T.; Gomes Filho, E.; Miranda, R. de S. Physiology and biochemistry of plants growing under salt stress. In: Gheyi, $\mathrm{H}$. R.; Dias, N. da S.; Lacerda, C. F. de; Gomes Filho, E. Manejo da salinidade na agricultura: Estudos básicos e aplicados. Fortaleza: INCTSal, 2016. Cap.12, p.163-180.

Sá, F. V. da S.; Brito, M. E. R.; Ferreira, I. B.; Antônio Neto, P.; Silva, L. A.; Costa, F. B. Balanço de sais e crescimento inicial de mudas de pinheira (Annona squamosa L.) sob substratos irrigados com água salina. Irriga, v.20, p.544-556, 2015. https://doi.org/10.15809/ irriga.2015v20n3p544
Sá, F. V. da S.; Pereira, F. H. F.; Lacerda, F. H. D.; Silva, A. D. Crescimento inicial e acúmulo de massa seca de cultivares de mamoeiro submetidas à salinidade da água em cultivo hidropônico. Revista Brasileira de Ciências Agrárias, v.8, p.435440, 2013. https://doi.org/10.5039/agraria.v8i3a2663

Santos, H. G.; Jacomine, P. K. T.; Anjos, L. H. C. dos; Oliveira, V. A. de; Lumbreras, J. F.; Coelho, M. R.; Almeida, J. A. de; Cunha, T. J. F.; Oliveira, J. B. de. Sistema brasileiro de classificação de solos. 3.ed. Brasília: Embrapa Informação Tecnológica, 2013. 353p.

Santos, J. L.; Matsumoto, S. N.; D’Arêde, L. O.; Luz, I. D.; Viana, A. E. S. Propagação vegetativa de estacas de Passiflora cincinnata Mast. em diferentes recipientes e substratos comerciais. Revista Brasileira de Fruticultura, v.34, p.581-588, 2012. https://doi.org/10.1590/ S0100-29452012000200033

Santos, V. A. dos; Ramos, J. D.; Laredo, R. R.; Silva, F. O. dos R.; Chagas, E. A.; Pasqual, M. Produção e qualidade de frutos de maracujazeiro-amarelo provenientes do cultivo com mudas em diferentes idades. Revista de Ciências Agroveterinárias, v.16, p.3340, 2017. https://doi.org/10.5965/223811711612017033

Silva Júnior, L. G. de A.; Gheyi, H. R.; Medeiros, J. F. de. Composição química de águas do cristalino do Nordeste Brasileiro. Revista Brasileira de Engenharia Agrícola e Ambiental, v.3, p.11-17, 1999. https://doi.org/10.1590/1807-1929/agriambi.v3n1p11-17

Sousa, A. B. O.; Bezerra, M. A.; Farias, F. C. Germinação e desenvolvimento inicial de clones de cajueiro comum sob irrigação com água salina. Revista Brasileira de Engenharia Agrícola e Ambiental, v.15, p.390-394, 2011. https://doi. org/10.1590/S1415-43662011000400010

Taiz, L.; Zeiger, E.; Møller, I. M.; Murphy, A. Fisiologia e desenvolvimento vegetal. 6.ed. Porto Alegre: Editora Artmed, 2017. 858p.

Teixeira, P. C.; Danagemma, G. K.; Fontana, A.; Teixeira, W. G. Manual de métodos de análise de solo. 3.ed. Brasília: Embrapa Informação Tecnológica, 2017. 573p.

Tsukamoto Filho, A. A.; Carvalho, J. L. O.; Costa, R. B.; Dalmolin, Â. C.; Brondani, G. E. Regime de regas e cobertura de substrato afetam o crescimento inicial de mudas de Myracrodruon urundeuva. Floresta e Ambiente, v.20, p.521-529, 2013. https:// doi.org/10.4322/floram.2013.032

Vallone, H. S.; Guimarães, R. J.; Mendes, A. N. G.; Cunha, R. L.; Carvalho, G. R.; Dias, F. P. Efeito de recipientes e substratos utilizados na produção de mudas de cafeeiro no desenvolvimento inicial em casa de vegetação, sob estresse hídrico. Ciência e Agrotecnologia, v.34, p.320-328, 2010. https://doi.org/10.1590/ S1413-70542010000200008

Zonta, H. J.; Braun, H.; Reis, E. F.; Paulucio, D.; Zonta, J. B. Influência de diferentes turnos de rega e doses de hidroabsorvente no desenvolvimento inicial da cultura do café conillon (Coffea canephora Pierre). Idesia, v.27, p.29-34, 2009. 